\title{
EU - RUSSIA : PARTNERSHIP AND COOPERATION
}

\author{
Esra HATiPOĞLU*
}

\begin{abstract}
Since 1989, when the Community concluded a comprehensive agreement with the Soviet Union on the basis of Anticles 113,228, and 235 of the EEC Treaty, which was to constitute an essential part of the normalization of mutual relations, both the $E C$ and the Soviet Union have undergone considerable changes. While EC was transforming into EU and remaining a key organization in Europe by reinforcing the integration among its members through the Treaty of European Union, the Soviet Union had disintegrated. Thus with the breakup of the Soviet Union, the balance of power in the EU had also changed; its potential eastern limits became more blurred than ever and EU was forced to revive its policies concerning the formal states of the eastern bloc.

In late 1991, EU had first realized that the original agreement which was signed with the USSR in 1989, had to be replaced with new agreements, due to the formation of a number of successor states of varying size and structures. Thus the EU opted a new approach to its future relations with the new republics through partnership and cooperation agreements which are intended to fall somewhere between a trade and cooperation agreement and an association agreement.

In 1994, agreements were signed with the ex-Soviet republics that laid down the framework for future political, commercial and cultural cooperation and set down a new legal basis for the development of trade and investment links. The partnership agreement with Russia also established regular political dialogue and supported Russia's transition to market oriented economic system based on human rights and democratic principles.
\end{abstract}

The EC which signed a trade and cooperation agreement with the Soviet Union in December 1989, after the disintegration of the USSR, had to negotiate additional

- Research Assistant, Marmara University EC Institule. 
trade and cooperation agreements with individual ex-Soviet republics. Since Russia is the legal successor to the ex-Soviet Union, the trade and cooperation agreement had become an agreement with Russia. The EC Commission, with a proposal to the Council in January 1992, indicated that a new approach was needed for future relations between the EC and the new republics. The Commission's then VicePresident Franz Andriassen, indicated that the Commission considered the first generation trade and cooperation agreements to be insufficient as regards the new states transforming to a market economy. Since the new states did not fulfill the economic and political requirements, it was obvious that there could not be any association agreements with those countries. Thus the Commission suggested the conclusion of an intermediate type of agreement which would provide support for the democratic process and the opening of the markets. In January 1992, the EC Council authorized the Commission to start preliminary discussions with four republics including Russia, for new trade and cooperation agreements which would go beyond the framework of the first generation trade and cooperation agreements, but would not take the form of association agreements. These new types of agreements - Partnership and Cooperation Agreements would remain as non-preferential agreements based on GATT principles of Most Favoured Nation (MFN), which means that in principle the concerned countries would not receive a better treatment from the Community than other GATT countries.

Bilateral negotiations with Russia began at the end of 1992 and was completed in the first half of 1994. After delays in concluding negotiations, because of disputes over banking and trade in nuclear materials, the Partnership and Cooperation Agreement was finally signed in Corfu, in June 1994'. It was similar to the Europe Agreements signed with the Eastern and Central European countries in structure, although different in content.

\section{Partnership and Cooperation Agreement}

In the Preamble of the Partnership \& Cocperation Agreement between Russia and EU the parties state their determination to work together and to strengthen the political and economic freedoms which constitute the very basis of the partnership. The parties also state their belief in the importance of the rule of law, respect for human rights, the establishment of the multiparty system with free and democratic elections and economic liberalization leading to a market economy. The parties also link the implementation of the Partnership and Cooperation Agreement to the continuation and the accomplishment of the political and economic reforms in Russia. The 
parties declare their full commitment to the full implementation of all principles and provisions contained in the Final Act of the CSCE, the concluding documents of the Madrid and Vienna Follow-up Meetings, the Document of the CSCE Bonn Conference on Economic Cooperation, the Charter of Paris for a new Europe and the CSCE Helsinki Document 1992 - "The Challenges of Challenge". In this sense, however, it is more important to translate all these declarations of intent into political practice.

In the Preamble, the parties also state that Russia is no longer a state trading country but rather a country with an economy in transition while in its own agreement with EU, Ukraine, for example, continued to be regarded as a state trading country.

However, unlike the Europe Agreements, the Partnership Agreement's Preamble does not refer to the process of European integration or the objective of EU membership, instead the agreement with Russia aims a gradual rapproachment between Russia and the EU and a wider area of cooperation. Under Article $O$ of the Treaty on European Union "any European country may apply to become a member of the Union". However, the definition of "European" has not been clearly explained yet. The Commission explains that the concept has geographical, historical and cultural elements. Thus this agreement although provides a framework for closer cooperation between the EU and Russia, does not envisage any membership to the EU in the forseeable future.

As far as the General Principles are concerned, the Agreement specifies that democracy, a market economy, and human rights are essential elements of the agreement, violation of which could result in suspension of it. However, the Economic and Social Committee, in its report, regards all these principleses highly unsatisfactory and criticized the Community in its failure to make the introduction and maintenance of market economy principles an integral part of the agreement with Russia. The Committee thinks that the absence of this element may give a false political sign, which can discourage Russia's market oriented reformers. The Committee also requires the maintenance of social and minority rights as an important part of the agreement.

Within the agreement itself, there is also an evolution clause under which a joint study is to be carried out in 1998 to establish whether the economic preconditions have been fulfilled in Russia, thus enabling negotiations to begin, on the establishment of a free-trade zone. However, the wording of this provision is also very vague. It doesn't give a clear explanation of the arrangements concerning the beginning of negotiations ${ }^{3}$.

3 Article 3, Russia PCA. 
Article 6 of the Partnership Agreement concerning the political dialogue between the parties, closely follows the political dialogue clauses of the Europe Agreements. The parties agree to strenghten links and political relations, to have convergence of positions on international issues of mutual concern. However, the absence of rights and opportunities for the development of minorities, as a part of the political dialogue, is the great deficit of the article involved. Within this framework, the parties also agree that regular meetings will take place in principle twice a year, between the Russian President and the President of the EC Council and the European Commission ${ }^{4}$. At the ministerial level, political dialogue will be conducted through the Cooperation Council and at the parliamentary level through the Parliamentary Cooperation Council. In addition, it is also specified that other procedures and mechanisms will be developed either through the use of diplomatic channels or via meetings of senior officials or experts 5 .

With this new agreement, the parties continue to grant each other Most Favoured Nation status within the meaning of Article I of the GATT; a status which had already been granted by the 1989 EC-Soviet Agreement. But any bilateral advantages which Russia grants to adjacent countries to facilitate frontier traffic, advantages granted with the aim of creating a customs union or a free-trade area, or the advantages granted to particular countries in accordance with GATT or international organizations are stated as exceptions ${ }^{6}$.

The parties also agree on the reciprocal abolition of quantitative export restrictions without prejudice for the special rules for textiles, ECSC products and nuclear materials. However, the safeguard clause agreed in the event of market disturbances which does not accord with GATT provisions, the anti-dumping and countervailing measures are not clear enough. The Community also could not agree on constant and common external tariff with Russia. Indeed the limit on quantitative restrictions does not cover measures having equivalent effect?

The anti-dumping and countervailing measures are based on Articles $\mathrm{VI}$ and $\mathrm{XVI}$ of the GATT and on internal rules based on EC dumping regulations. Since the provision is not very clear, the parties have to deal with the problems on ad hoc basis. The classification of Russia as a state in transition has some impacts on the antidumping duties. Thus Article 2(5) of the anti-dumping regulation dealing with the determination of the normal value of imports from non-market economy countries will not be applied to Russia.

\footnotetext{
4 Arts. 8 \& 9., Russia PCA.

5 Arts. $8 \& 9$.

6 Article 10.

7 Arts. 12-21.
} 
On the other hand, the specific problems of individual sensitive sectors force the parties to have a number of ancillary provisions on goods trade. Thus, temporary protective measures have to be included in the Partnership and Cooperation Agreements to facilitate a social safety net for the inevitable restructuring in the textiles and the ECSC areas.

A voluntary export restraint (VER) agreement on trade in textiles was signed between the Community and Russia by which the parties underlined their desire to promote an unhindered and balanced development of trade in textiles. On the other hand, the discussions on VER agreements concerning the imports of certain steel products for 1995 and 1996 were concluded at the end of 1994 which envisaged an increase in supply opportunities by \% 35 in 1995 and another \% 15 in 1996. In the agreement, the parties also agreed on the creation of a contact group on coal and steel matters that would ensure the exchange of information of common interests relating to these products. The details then emerged on the imports of steel products. A series of Commission decisions ${ }^{8}$ had appeared that set out details on licensing of imported products and ensured checks on their origin and required the Member States to make monthly reports to the Commission on imports. On the other hand, the Commission Decision 96/8/ECSC which gave effect to the Agreement between the ECSC and Russia on steel trade, signed in March 1995 set out mechanisms for ensuring stability in trade and provide consultations in the event of disputes over volume or price of imports into the EU.

The quantitative limits under these two accords are :

1995

1996

PRODUCTS

(TONNES)

A. Flat Products

1. Coils

152.163

174.988

2. Heavy Plates

36.455

41.923

3. Other flat prod.

22.343

25.695

B. Long Products

1. Beams

12.854

14.782

2. Wire rod

3. Other long prod.

68.652

78.950

Source: European Report, No.: 2098, January 13, 1996. 
The negotiations on trade in nuclear materials cld not be finished within a short period of time due to the differences of opinion between the parties. Since the Community feared that imports of enriched uranium from Russia could threaten the viability of its own industries, the Agreement could not have the same rules applied to general trade in goods for the nuclear materials. Thus they agreed to have a special agreement concerning trade in nuclear materials whose negotiations began in Janvary 1997. The parties then agreed that until such an agreement has been concluded, the respective legislation and non-proliferation obligations of the parties will be applicable to the transfer of nuclear materials ${ }^{10}$.

With regard to the labour conditions, the parties agree not to allow any nationality-based discrimination as regards renumeration or dismissal and working conditions and not to discriminate against the other party's nationals legally employed on their territory". However, the families of the workers are not given access to the Community labour market. The parties also state their desire to make joint efforts to control and prevent illegal immigration and to coordinate the social rights of Russian workers who are legally employed in the Community. Thus, this coordination will ensure that worker's periods of insurance, employment or residence completed by such workers in the various Member States will be added together for the purpose of medical care and retirement and pensions in respect of old age and invalidity ${ }^{12}$. The Cooperation Council is given the task of making reconmendations for the implementation of labour conditions.

In case of the freedom of establishment Russia and the Community grant each other reciprocal Most Favoured Nation status for the establishment of enterprises (subsidiaries and branches) on each other's territory, but they also have some reservations in some areas. The Community and Russia grant each other MFN status only in case of operations of branches of companies ${ }^{13}$. Concerning banking services, the Agreement with Russia however places Community banks at a clear competitive disadvantage due to some problems; the general ceiling on foreign ownership of Russian banks (\% 12), the limit on the number of branches of Russian subsidiaries of EC banks, the rule that the subsidiaries have to be more highly capitalized than Russian banks, the prohibition of trade in shares and instruments convertible to shares of Russian companies ${ }^{14}$. But by 1996 , Russia abolished the Yeltsin Decree of 17 November 1993 which maintained curbs on foreign banks handling business concerning Russian customers.

10 Article 22., Russia PCA.

11 Article 23.

12 Article 24.

13 Article 28.

14 Article 29, Russia PCA. 
Concerning services, both parties lay down the reciprocal MFN concessions for a broad range of services. In the future, the Cooperation Council will make recommendations for further liberalization of the cross-border trade in services by taking into account the other international commitments entered into by the parties ${ }^{15}$.

With regard to maritime transport, the parties agree to apply the principle of unrestricted access to the international market and traffic on commercial basis. Since the provisions concerning the transport sector are inadequate, the parties agree to make some additional special agreements following the entry into force of this Partnership Agreement ${ }^{16}$.

Concerning current payments and capital movements, the Agreement with Russia includes provisions for compensation for expropriation, nationalization or measures having equivalent effect. After a five-year period, the parties agree not to introduce any further restrictions on cross-border capital movements ${ }^{17}$.

With regard to competition, although the parties are directly required to accept and enforce laws addressing restrictions on competition by enterprises within their jurisdiction, the overall wording of Article 53, unlike the Europe Agreements, is soft and non-binding. However, there is that general agreement with Russia to refrain from granting subsidies in trade for exports to the Community that favour certain undertakings. Russia also agree to introduce strict aid discipline in its trade with the Community from the third year onwards.

By this agreement, the parties confirm the importance they attach to the protection of intellectual, industrial and commercial property rights. Thus Russia state its intention to strengthen the protection of these rights and to achieve a level of protection comparable with the EC within five years after the Agreement's entry into force ${ }^{18}$.

Russia also promise to make its legislation compatible with that of the Community. Due to the difficulty of the process there is no timetable for the approximation of laws between Russia and the Community ${ }^{19}$.

Concerning economic cooperation, the parties also express their wish to foster economic cooperation to increase economic links between themselves. The areas for cooperation are also tried to be listed under Article 56 of the Partnership Agreement. However, making merely the long list of policy areas may not be sufficient for the real

15 Arts. 36-38., Russia PCA.

16 Arts. 39-43.

17 Article 52.

18 Article 54, Russia PCA.

19 Article 55. 
implementation of economic cooperation. Thus a sufficient division of responsibility that will complete the process between the parties has to be made ${ }^{20}$. Within this context, the listing of the priority areas for cooperation between the parties can also be helpful.

On the other hand, in contrast to the Europe Agreements, the Agreement with Russia for the first time contains a list of areas for cooperation on prevention of illegal activities, ranging from illegal immigration and illegal presence of physical persons to illegal activities in the sphere of economics, illegal transactions of various goods and to the illicit traffic of narcotic drugs ${ }^{2 t}$.

Also by virtue of the Agreement, Russia will benefit from the technical assistance in the form of grants under the Community's TACIS programme ${ }^{22}$.

As far as the institutional framework is concerned, a Cooperation Council consisting of members of the Council of the EU, members of the Commission of the European Communities and members of the Government of Russia, is established to supervise the implementation of the Agreement ${ }^{23}$. There is also a Cooperation Committee composed of representatives of the Council, Commission and Russia who assists the Cooperation Council in the performance of its duties ${ }^{24}$.

Together with all these important provisions, there are also some provisions concerning industrial cooperation, investment promotion, public procurement, consumer protection, science, technology, education and training, energy, environment, transport, telecommunications, financial services, regional development, tourism and cultural cooperation ${ }^{25}$. Thus, once ratified, the Agreement will cover a wide range of EU/Russia trade, commercial and economic relations. Together with these developments, it also includes political dialogue. However, until its ratification, an Interim Agreement on trade and trade-related matters was signed in Brussels in July 1995 that would make the implementation of the trade-related provisions possible without waiting for the ratification of the full Agreement by the European Parliament, Parliaments of the Member States and the Russian Federation. The EU/Russia Interim Trade Agreement covers trade in goods, payments, competition, economic cooperation relating to standards and conformity assessment and customs ${ }^{26}$ came into force in February 1996. By this agreement, the EU get improved access to the Rus-

21 Article 84, Russia PCA.

22 Arts. 86-89.

23 Arts. 90-91.

24 Article 92.

25 Arts. 57-85.

$26 \operatorname{COM}(95), 268,22.7 .1995$. 
sian market for cars and alcoholic beverages and many quantitative import restrictions are decreased. At the same time, Russian exports to the EU are facilitated by the abolition of several quantitative restrictions while the scope of EU commercial instruments are reduced.

The European External Relations Commissioner Hans van den Broek had visited Moscow in March 1996. In his speech at the Carnegie Foundation he stated both the common points and the problems between the EU and Russia. Due to the importance of the relations with the EU, there were also some high level series of meetings during his stay with the Foreign Minister, first deputy Prime Minister, deputy of the Prime Minister and delegations from the Committee for International Relations of the Duma, concerning both political and economic reform and the implementation of the Interim Agreement. He stated the possibility of using EU aid for increasing competitiveness in the Russian textile industry. He also stated the EU desire for getting more information on the minimum price imposed on EU imports of vodka.

Concerning the EU-Russian relations, there is also the Political Declaration signed by the Presidents of Russia, the European Council and the European Commission in November 1993, which provides the basis for permanent political dialogue and a system of regular consultations ${ }^{27}$.

Under TACIS arrangement, the new programme that will last in 1999 concentrate on enterprise restructuring and development, human resource development and food production like the previous programme, but it also includes new instruments like cross-border cooperation and equity capital for small and medium enterprise (SME) joint ventures. The regional funds will also continue. On the other hand, the new joint EU-Council of Europe programme will provide ECU 1.2 million to strengthen the public administration. The EU continues to be the largest single provider of humanitarian aid ${ }^{28}$.

On the other hand, during talks between European Commission President Jacques Santer, the Russian President Boris Yeltsin and the Prime Minister Viktor Chernomyrdin in April 1996 in Moscow, during the G-7 nuclear safety summit, the Russian delegation asked the EU to lend more money through the European Investment Bank for investment in Russia. On the other side, the European Commission President asked for a better business climate ensuring the confidence in legal, administrative and taxation systems. The action by the EIB was favoured by the EU but there had to be a change in the statute of the bank. During these bilateral talks Russia also stated its wish in linking up to the trans-European networks ${ }^{26}$.

27 Bulletin EC 11 1993, p. 71.

28 Fact Sheets on the European Parliament and the Activities of the EU, 1996 p. 126-127.

29 European Report, No: 2126, April 24, 1996, p. 54. 
As far as the bilateral trade problems are concerned, the Russian officials queried the EU's import quotas for textiles. The EU complained about the difficulties which the EU craft flying over Siberia had and the problems of the EU pharmaceuticals companies in getting into the Russian market. On the other hand, Russia again in April 1996 announced to suspend the import taxes applied since March on foreign aicohol but not on vodka ${ }^{30}$.

In May 1996, the EU prepared an action plan on Russia which represented refinement of the continuing EU efforts to construct a coherent policy over its relations with Russia. The plan, after stating the determination of the EU in establishing a solid partnership with Russia, included such principles like human rights, consolidation of peace, etc.. It also included some points like the EU involvement as an observer in the June 1996 elections, helping align Russian constitutional and judicial legislation with Council of Europe norms, support for interparliamentary and youth cooperation and training programmes for lawyers, programmes for city twinning and local authority support, consolidation of existing support for Russia's WTO accession, encouragement for regional cooperation with CEECs, the Baltic region and with the CIS countries, help in adapting energy legislation, establishment of independent regulation of the nuclear sector, assistance in developing industrial competitiveness, joint work to fight crime, cooperation on migration and asylum law, intensification of contacts within existing security and disarmanent mechanisms, reinforcement of the OSCE role in Chechnya, tighter controls on nuclear trafficking, cooperation on foreign policy and on enhanced contacts between the EU and Russian diplomats and the opening of discussions with Russia on preventive diplomacy ${ }^{31}$. Thus by this Action Plan, the EU is committed to establish a substantial partnership with Russia in order to promote a reform process in this country.

\section{Conclusion}

Despite that proper legal fromework, however the future course of development in the relations between the EU and Russia will mostly depend on the success or the failure of the attempts made within Russia to restructure its policies, its economy, and its society, and also the outcome of the controversies over the nature and cohesion of Russian statehood.

Whatever the situation will be, the intensification of political and economic relations between the EU and Russia, however, can not be directed towards the objective of Russia's eventual full integration into the Union ${ }^{2}$. On the other hand, de-

30 Ibid, p. 57.

31 European Report. No.: 2131, May 11, 1996.

32 Höhmann H., Meier C., Timmermann H., The European Community \& the Countries of the CIS: Political \& Economic Relations", The Joumal of Communist Studies, vol: 9, no: 3, Sep 93, p. 159. 
spite the fact that the EU became the first Western institution to sign a comprehensive trade agreement with Russia, the relations have not normalized yet due to some political issues like the debate over NATO enlargement, disposal of nuclear weapons and human rights abuses, especially in Chechnya, which can not be settled by the trade agreement concluded.

On the other hand, the agreements signed represent a formal recognition that there is a CIS track and an Eastern track for relations with the EU. Russia is obviously the most important country within the CIS track. Thus the agreement with Russia also recognizes this fact with its enhanced political dialogue and detailed provisions on investment.

The Partnership Agreement is regarded partly as an entry-level agreement that assist Russia in integrating into the world economy. Within this context, 1998 is given as the latest year for beginning negotiations on a free trade area and it is accepted that after one year of negotiations and a 10-year transition period, the free trade would likely be completed until 2009, but the negotiations could begin earlier if EU wants it ${ }^{33}$.

The EU sees Russia as a steady and long-term partner, but this process depends mainly on internal developments within Russia. Some of the statements of Zhirinovsky, for example, are contrary to fundamental values of the EU. If such ideas become Russia's real policies, than EU-Russian relations could be affected in a negative way. 


\section{BIBLIOGRAPHY}

Bulletin EC - 111993.

CES (95), 55, 26.1.95.

European Report, no: 2126, April 24, 1996.

European Report, no: 2131, May 11, 1996.

Fact Sheets on the European Parliament \& the Activities of EU, 1996.

Höhmann $\mathrm{H}$, Meier $\mathrm{C}$, Timmerman $\mathrm{H}$. "The European Community and the Countries of the CIS; Political and Economic Relations", The Joumal of Communist Studies, vol: 9, no: 3, Sep 93.

The Partnership \& Cooperation Agreement between Russia and European Union [COM (94), 257, 15.6.1994].

Steve Peers, "From Cold war to Lukewam Embrace: The European Union's Agreements with the CIS", International and Comperative Law Quarterly, vol: 44, part: 4, October 95. 